\title{
A Study on the Selective Controls of Inventory Management And Application of ABC XYZ Control Matrix in the Cardiology Department of A Tertiary Care Hospital.
}

\author{
Dr.K.V.Krishna Reddy ${ }^{1}$ Dr.M.S.Siddarth Sai ${ }^{2}$ Dr.Rakesh Prabhu ${ }^{3}$ \\ ${ }^{1,2,3}$ Asst Professor,Dept of Hospital Administration, NIMS
}

\section{Introduction}

Heath care demand and supply cannot be left to be regulated solely by the invisible hand of the market. Nor can it be established on considerations of utility maximizing conduct alone ${ }^{6}$. Materials management is an important issue for healthcare systems because it influences clinical and financial outcomes ${ }^{7}$. Hospital materials management (HMM) also involves the clinical sphere of healthcare service performance ${ }^{7}$. The item list changes from hospital to hospital, depending not only on the healthcare services managed, but also on the physician's expertise and preferences, and following pharma co-economics principles ${ }^{8}$ Effective and efficient of inventory management system can affect supply chain management significantly to improve cycle service levels and reduce $\operatorname{costs}^{1}$ Organizations should ensure that they take specific actions to optimize the inventory level with the minimum total annual inventory cost and they implement the actions consistently. But, to determine which actions are the right ones for the organization, they first carry out the detailed analysis of the inventory. The results of the analysis can be used as a basis for defining the appropriate inventory optimization measures ${ }^{2}$

Classification of selective controls

\begin{tabular}{|c|c|c|}
\hline Type of control & Basis & Main use \\
\hline $\begin{array}{l}\text { Abc [always better control/ pareto's } \\
\text { law] }\end{array}$ & $\begin{array}{l}\text { Value of consumption of items } \\
\text { concerned [it has nothing to do with } \\
\text { unit value of the time] }\end{array}$ & $\begin{array}{l}\text { To control raw material components and } \\
\text { WIP of business }\end{array}$ \\
\hline $\begin{array}{l}\text { HML } \\
\text { [High, Medium, Low] }\end{array}$ & $\begin{array}{l}\text { Unit price of the material [opposite to } \\
\mathrm{ABC} \text { ] }\end{array}$ & To control purchases \\
\hline $\mathrm{XYZ}$ & Value of items in storage & $\begin{array}{l}\text { To review the inventory, their uses etc. at } \\
\text { scheduled interval }\end{array}$ \\
\hline $\begin{array}{l}\text { VED } \\
\text { [vital, Essential, Desirable] }\end{array}$ & Critically of the items & $\begin{array}{l}\text { To determine the stocking levels of spare } \\
\text { parts }\end{array}$ \\
\hline $\begin{array}{l}\text { FSN } \\
\text { [Fast moving, Slow moving and Non } \\
\text { moving] }\end{array}$ & Consumption pattern of the items & To control obsolescence \\
\hline $\begin{array}{l}\text { SDE } \\
\text { [Scarce, Difficult and easy to obtain] }\end{array}$ & Problems faced in procurement & $\begin{array}{l}\text { Lead time analysis and purchase } \\
\text { strategies }\end{array}$ \\
\hline $\begin{array}{l}\text { GOLF } \\
\text { [Govt.Ordinary,LocaForeign } \\
\text { sources] }\end{array}$ & Sources of supply & Procurement storage \\
\hline $\begin{array}{l}\text { SOS } \\
\text { [Seasonal and Off seasonal] }\end{array}$ & Nature of supplies & $\begin{array}{l}\text { Procurement and holding strategies for } \\
\text { seasonal items like agricultural products. }\end{array}$ \\
\hline PQR & Shelf life of items & $\begin{array}{l}\text { To have control over items based on their } \\
\text { expiry dates. }\end{array}$ \\
\hline
\end{tabular}

Need for the Study:

It is not uncommon for us to hear that a life saving drug was not available in a particular hospital or several other items became obsolete due to overstocking. Management by Objectives (MBO) concentrates on identifying key result areas and performance standards and 50 percent of these are usually covered by 20 percent of his activities.

Cardiology department contributes a major share to the revenue generated by the hospital. Most of the revenue generated by the department is due to the procedures performed in the cath lab and hence was selected for the study.

\section{Objectives:}

1. To classify the items in cath lab stores into A,B and C category depending upon their value of consumption and suggest procedures to be adopted to control A,B and $\mathrm{C}$ items.

2. To classify the items in cath lab stores into $\mathrm{X} Y$ and $\mathrm{Z}$ category based on the closing stock as on $31 / 03 / 2016$. 


\section{Methodology}

The study was carried out in the Cath lab stores of Nizam's institute of medical sciences, a tertiary care teaching hospital.

A retrospective study of the data of cath lab stores during the period of April 1, 2015 to March 31, 2016 was done.

The following information was gathered from the stock records.

* Opening \& Closing balance of stock

* Issues \& Receipts

* Price of individual items

Data collected was entered and analyzed in Microsoft Excel.

Observations and analysis:

Distribution values of consumption of Cath lab stores Inventory

\begin{tabular}{|l|l|l|l|l|l|}
\hline S.no & Items & Class of items & $\%$ of items & Value of Cons & Cons value $\%$ \\
\hline 1 & 18 & A & 10 & 56313839 & 63 \\
\hline 2 & 36 & B & 20 & 25165853 & 28 \\
\hline 3 & 124 & C & 70 & 8019606 & 9 \\
\hline Total & 178 & & 100 & 89499298 & 100 \\
\hline
\end{tabular}
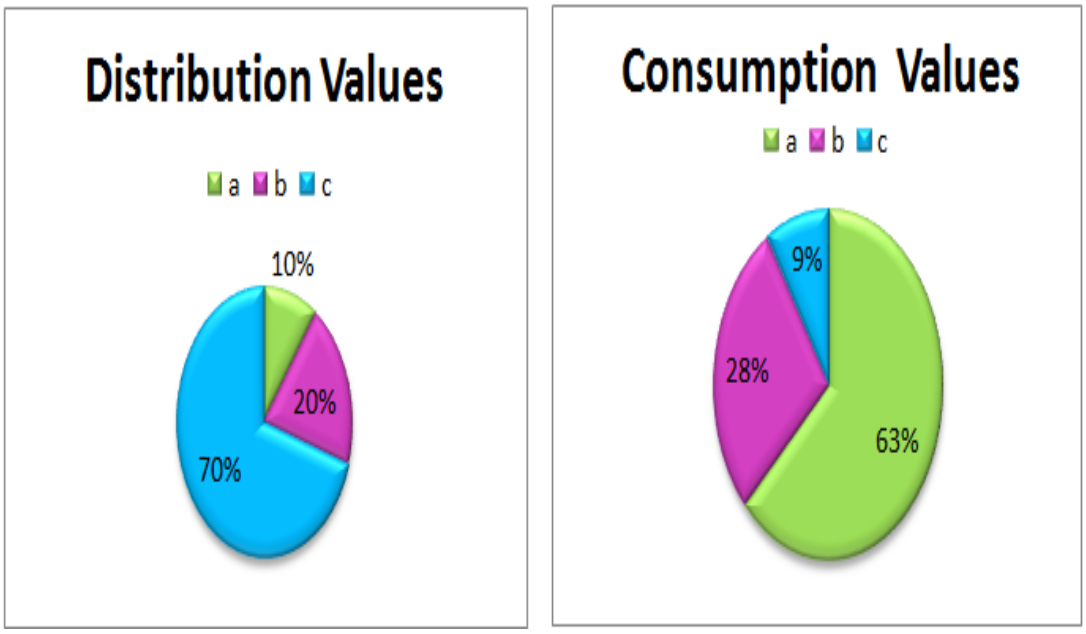

\section{ABC analysis:}

$\mathrm{ABC}$ analysis is an important tool used worldwide, identifying items that need greater attention for control $^{2}$. Before an inventory management is done, an $\mathrm{ABC}$ classification is usually undertaken ${ }^{4}$. ABC analysis is a method of classifying items according to their relative importance. It is also known as "separating the vital few from trivial many" 3 . ABC analysis identifies the drugs requiring stringent control for optimal use of funds and elimination of out-of-stock situations in the pharmacy ${ }^{5}$

Selective Control Procedures for ABC Items

\begin{tabular}{|l|l|l|l|}
\hline CONTROL & A-ITEMS & B-ITEMS & C-ITEMS \\
\hline $\begin{array}{l}\text { Type of control and } \\
\text { Authority }\end{array}$ & Very strict control. & $\begin{array}{l}\text { Low control, powers can be } \\
\text { delegated } \\
\text { department. } \\
\text { the }\end{array}$ \\
\hline Quantity of safery stock & $\begin{array}{l}\text { Very low or practically } \\
\text { nil, safety stock combined } \\
\text { with frequent ordering } \\
\text { and/or staggered supplies }\end{array}$ & $\begin{array}{l}\text { Low safety stock ordering } \\
\text { can be done monthly or } \\
\text { quarterly }\end{array}$ & $\begin{array}{l}\text { High safety stock and bulk } \\
\text { ordering half yearly or annual } \\
\text { orders to take advantage on } \\
\text { bulk discounts }\end{array}$ \\
\hline Consumption control & Regular - weekly or daily & Fortnight or a month & $\begin{array}{l}\text { The period can be extended to } \\
\text { a quarter }\end{array}$ \\
\hline Material planning & $\begin{array}{l}\text { Material planning should } \\
\text { be accurate and data base } \\
\text { should be up to date }\end{array}$ & $\begin{array}{l}\text { Past consumption can be } \\
\text { used a basis for plans data } \\
\text { can be 10 to 15days old }\end{array}$ & $\begin{array}{l}\text { Rough estimates are sufficient } \\
\text { and data can lag behind by a } \\
\text { month }\end{array}$ \\
\hline
\end{tabular}

\begin{tabular}{|ll|l|l|l|}
\hline $\begin{array}{l}\text { Applications of value } \\
\text { analysis }\end{array}$ & $\begin{array}{l}\text { A concerted attempt } \\
\text { should be made at value } \\
\text { analysis, waste, } \\
\text { reduction, obsolete and } \\
\text { surplus reduction }\end{array}$ & $\begin{array}{l}\text { Moderate attempts } \\
\text { are sufficient }\end{array}$ & Annual reviews sufficient \\
\hline Numbers of sources of & Increase the number of & 2 or 4 reliable 1 or 2 reliable sources, \\
\hline
\end{tabular}




\begin{tabular}{|c|c|c|c|}
\hline supply & $\begin{array}{l}\text { sources, centralize } \\
\text { purchase and stores and } \\
\text { reduce lead time }\end{array}$ & $\begin{array}{l}\text { sources combined } \\
\text { purchase with } \\
\text { moderate attempt } \\
\text { to reduce lead time }\end{array}$ & $\begin{array}{l}\text { Annual or Half yearly } \\
\text { purchases. } \\
\begin{array}{l}\text { Decentralized and reduce } \\
\text { clerical work }\end{array}\end{array}$ \\
\hline Lead time reduction & $\begin{array}{l}\text { Maximum efforts } \\
\text { should be made to } \\
\text { reduce lead time }\end{array}$ & Moderate efforts & Minimum clerical efforts \\
\hline Centralized vs. Decentralized & Centralized purchasing & $\begin{array}{l}\text { Combination } \\
\text { purchasing }\end{array}$ & Decentralized purchasing \\
\hline Priority & $\begin{array}{ll}\text { High priorities in all } \\
\begin{array}{ll}\text { activities } \\
\text { procurement stage }\end{array} \\
\end{array}$ & $\begin{array}{l}\text { Normal processing } \\
\text { with high priority } \\
\text { only when critical }\end{array}$ & Lowest priority \\
\hline
\end{tabular}

\section{Advantages of ABC Analysis}

1. This approach helps the Materials Manager to exercise selective control and Focus attention only on a few items when he is confronted with lakhs of items.

2. By controlling ' $A$ ' items and doing proper inventory analysis obsolete stocks are automatically pin pointed.

3. A B C analysis helps to rationalize number of orders and reduce average inventory.

4. It prevents wasting of time and energy in making improvements, where improvements yield marginal benefit ('C' class items)

5. It reinforces concepts of management by exception theory.

Limitations of $\mathrm{ABC}$ Analysis

1. $\mathrm{ABC}$ analysis, in order to be fully effective, should be carried out with standardization and codification.

2. It indicates nothing about their profitability or critically, importance to an item is given on the basis of its consumption value and not on criticality. Hence such a classification can lead to overlooking the need for spare part, whose critically is high but consumption value is low.

3. ABC analysis should be reviewed periodlically

4. The limitation of $\mathrm{ABC}$ analysis is that it is based only on monetary value and the rate of consumption of the item. In a hospital, an item of low monetary value and consumption may be very vital or even lifesaving.

\section{XYZ analysis}

The total closing stock value for each item is arranged in descending order The cumulative total closing stock value is computed for each item.

As shown in the table

X Class items: $10 \%$ of items contributing $59 \%$ of the total closing stock value

Y Class items: $20 \%$ of items contributing $35 \%$ of the total closing stock value

Z Class items: $70 \%$ of items contributing $6 \%$ of the total closing stock value

Distribution of Stocks in the stores as on 31/03/2014

\begin{tabular}{|l|l|l|l|l|}
\hline $\begin{array}{l}\text { No of } \\
\text { Items }\end{array}$ & Class of items & $\%$ of items & $\begin{array}{l}\text { Total closing stock } \\
\text { value. }\end{array}$ & $\begin{array}{l}\text { Total closing stock value } \\
\%\end{array}$ \\
\hline 7 & $\mathrm{X}$ & 10 & 1560865 & 59 \\
\hline 14 & $\mathrm{Y}$ & 20 & 925382 & 35 \\
\hline 52 & $\mathrm{Z}$ & 70 & 167623 & 6 \\
\hline 73 & & 100 & 2653870 & 100 \\
\hline
\end{tabular}

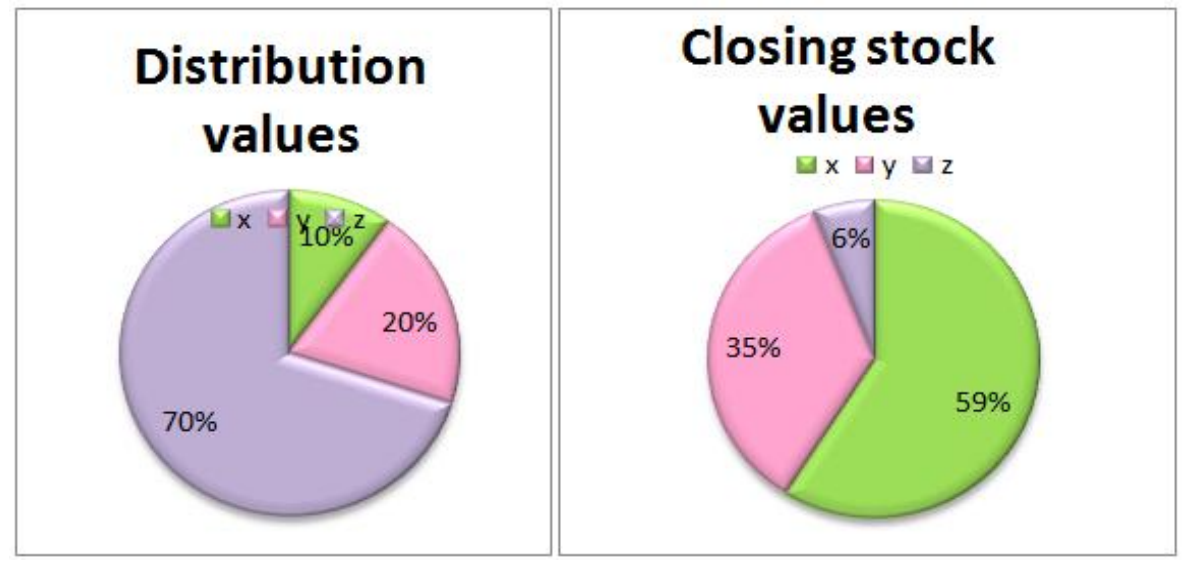


While $\mathrm{ABC}$ classification has the value of consumption as the basis, $\mathrm{XYZ}$ has the value of inventory stored as basis. The study is undertaken once a year at the time of annual stock taking. $\mathrm{X}$ items are those items whose stock values are high, while $\mathrm{Z}$ items are those items whose stock values are low. As expected, $\mathrm{Y}$ items fall in between two categories $\mathrm{X}$ and $\mathrm{Z}$. This classification helps in identifying the items, which are being excessively stocked. If the management is caught napping, one can expect ' $\mathrm{C}$ ' items in $\mathrm{X}$ category. Therefore $\mathrm{ABC}$ and $\mathrm{XYZ}$ controls in conjunction will help the managers to have better control.

Control Matrix for ABC and XYZ Items

\begin{tabular}{|l|l|l|l|}
\hline Class of Item & X-Items & Y-Items & Z-Items \\
\hline A-Items & $\begin{array}{l}\text { A critical analysis is needed } \\
\text { for reducing the stocks. }\end{array}$ & $\begin{array}{l}\text { Attempts must be made to } \\
\text { convert these items to 'Z' } \\
\text { category }\end{array}$ & Items are well under control. \\
\hline B-Items & $\begin{array}{l}\text { Consumption and stock } \\
\text { control must be reviewed } \\
\text { more frequently. }\end{array}$ & $\begin{array}{l}\text { No further action in control } \\
\text { may be necessary. }\end{array}$ & May be reviewed half yearly. \\
C-Items & $\begin{array}{l}\text { Action can be initiated to } \\
\text { dispose off excess stocks. }\end{array}$ & Controls should be tightened. & Can be reviewed annually. \\
\hline
\end{tabular}

XYZ analysis helps to control obsolescence. It tells how the values are distributed amongst materials in stores. The procedure to carry out XYZ classification is very simple. After annual stock taking, the closing stock values of items are arranged in descending order according to their values. The cumulative totals are entered against each item. The descending number of item is found as percentage of total value of all items in stores.

$\mathrm{ABC}$ and $\mathrm{XYZ}$ Control Matrix

\begin{tabular}{|l|l|l|l|l|}
\hline & & $\mathrm{X}$ & $\mathrm{Y}$ & $\mathrm{Z}$ \\
\hline \multirow{3}{*}{$\mathrm{A}$} & No of items & 4 & 1 & 1 \\
\cline { 2 - 5 } & Value & 1059235 & 24660 & 15840 \\
\hline \multirow{3}{*}{$\mathrm{B}$} & No of items & 2 & 0 & 2 \\
\cline { 2 - 5 } & Value & 501630 & 0 & 0 \\
\hline $\mathrm{C}$ & No of items & 0 & 13 & 49 \\
\hline & Value & 0 & 900722 & 151783 \\
\hline
\end{tabular}

\section{Conclusion}

The common sense approach to solving any problem is to tackle important aspects more rigorously. Similarly in inventory management, classification is adopted so that a major portion of effective managerial time is spent on those materials, which are more important. The motive behind any selective control is that equally detailed analysis of all items is very expensive. Moreover such a concentration on all items will have diffused effect regardless of the priorities. Selective inventory control can indicate where the manager should concentrate his efforts.

Peter F. Drucker, states that "One must look to the area where the results are, not where work is".

\section{References:}

[1]. S. Routroy and N. A. Bhausaheb, "Evaluation of Inventory Performance for Perishable Products through Simulation," The IUP Journal of Operation Management, vol. IX, no. 1\&2, 2010

[2]. Imelda Junita ,Rhessy ; ABC-VED analysis and Economic order interval-multiple items for medicines inventory control in hospitals ;International conference on business and management 2012.

[3]. Fitzsimmons J. A. and Fitzsimmons M. J. (2004), Service Management, Operations, Strategy,and Information Technology, Edn 2., Irwin McGraw- Hill, New York, 348 - 384

[4]. Devnani M, Gupta AK, Nigah R. ABC VED Analysis of the Pharmacy Store of a Tertiary Care Teaching, Research and Referral Healthcare Institute of India. Department of Hospital Administration 2010; 2: 201-205

[5]. Gupta S, Kant S. In: Hospital stores management - An integral approach. New Delhi: Jaypee Brothers Medical Publishers (P) Ltd; 2000. Inventory control; pp. $60-72$.

[6]. Planningcommission.gov.in/reports/genrep/bkpap2020/26_bg2020.doc

[7]. Raffele lannone et al; Modelling hospitals materials management processes; International journal of engineering business management ;2013

[8]. Integrating the Healthcare Enterprise (2012) IHE Pharmacy. Technical Framework Supplement. Hospital Medication Workflow, Trial Implementation. http://www.ihe.net/Technical_Framework/upload/IH E_Pharmacy_Suppl_HMW.pdf [accessed 5 November 2012].

[9]. Vaz FS, Ferreira AM, Kulkarni MS, Motghare DD, Pereira-Antao I. A Study of Drug Expenditure at a Tertiary Care Hospital: An ABC-VED Analysis’ Health Management. 2008;10: 